\title{
BEHAVIOR OF SOME MICRO NUTRIENTS IN RELATION TO THEIR GEOMORPHOLOGICAL UNITS IN FAR-WEST SOILS OF EL-MINYA - EGYPT
}

Abd El Salam M. Elwa* ; Walid F. Ramadan

and Ahmed M. Abou-Shady

Soil Chemistry and Physics Department- Desert Research Center, El-Mataria 11753, Cairo, Egypt

*Email- abdelsalamelwa33@yahoo.com

Key Words: Micro-nutrients; Heavy metals; geomorphological units; El-Minya.

\section{ABSTRACT}

This research aims to know the behavior of some microelements and relation to their geomorphological units in the far western soils of Minya, Egypt. Achieve this were collected twenty two samples of eight soils profiles in different locations at Far-West of El-Minya - Egypt. In this area, one of the huge national projects that the Egyptian governments. The obtained results showed that, the levels of available $\mathrm{Fe}, \mathrm{Mn}, \mathrm{Zn}, \mathrm{Cu}, \mathrm{Ni}$, and $\mathrm{Cr}$ were oscillated closely to the critical levels of international regulation. The correction between the studied heavy metals and both soil physical and chemical properties tended to be oscillated from element to another.

The concentrations of available Fe was higher than the critical levels of $2.5-2.6 \mathrm{mg} \mathrm{kg}^{-1}$ except for the first layer of soil profile number 1 . The Critical values of $\mathrm{Mn}$ in both sandy and calcareous soils were set to be 1.4 and $1.2 \mathrm{mg} \mathrm{kg}^{-1}$, respectively and accordingly, the concentrations of Mn in the studied soils profiles were lower that the critical levels particularly for soil profiles number 1 and 2. However, it was close to the critical levels in the rest of soil samples. Comparatively, high levels of Mn were observed with the deep layer of soil profile number 3 and the top layer of soil profile number 4. As it has set previously by different studies, the critical levels of $\mathrm{Zn}$ in the alluvial and calcareous soils were 0.9 and $0.7 \mathrm{mg} \mathrm{kg}{ }^{-1}$, respectively, samples that collected from soil profiles one and four were lower than or equal to the critical levels. The concentrations of available $\mathrm{Cu}$ in our study were oscillated among high to medium critical levels.

\section{INTRODUCTION}

The scarcity of water resources in several regions has caused panic for decision maker particularly for countries that are located among latitudes $35^{\circ} \mathrm{N}$ to $35^{\circ} \mathrm{S}$. In such latitudes the weather of arid and semi-arid is the common weather in addition to seven of largest deserts worldwide is existing. The Middle East and North Africa (MENA) countries are located within latitudes $35^{\circ} \mathrm{N}$ to $35^{\circ} \mathrm{S}$ that suffer from deficiency of water resources particularly for agriculture irrigation. Scarcity of water resources problem becomes nowadays more complicated because of the rapid increases of population simultaneously with socio-economic crises, political instability, and vulnerability of region. Most of Egyptian population's census living 
adjacent to the River Nile and account approximately 95 million which reinforce the importance of existing strong agricultural policy (AbouShady, 2016 a and Azzam, 2016; Abou-Shady, 2017; Kassim et al., 2018; Sayed et al., 2020).

In the present work, the vertical distribution of available heavy metals including in eight soil profiles $\mathrm{Fe}, \mathrm{Mn}, \mathrm{Zn}, \mathrm{Cu}, \mathrm{Ni}$, and $\mathrm{Cr}$ in Far-West of ElMinya - Egypt was studied. Samples were collected from eight soil profiles at different which represent the medium high terraces (soil profiles 1-4) and low high terraces (soil profiles 5-8). The correlation between the studied heavy metals and soil chemicals properties, particle size distribution, and textural classes were also investigated.

\section{MATERIALS AND METHODS}

Twenty two soil samples were collected from eight soil profiles representing the two the geomorphological units identified in Far-West of El-Minya (Fig. 1). The soil profiles were divided into two medium high terraces (soil profiles from 1 to 3 ) and low high terraces (soil profiles from 4 to 8 ). The soil profiles were morphologically considered and the whole samples of all profiles were air-dried, ground with a wooden pestle in agate mortar, sieved through a $2 \mathrm{~mm}$ sieve and subjected to the following analyses:

- Particle size distribution by the sieving, (Retsch 2009).

- Calcium carbonate content was determined using Collins calcimeter (Horvath et al., 2005).

- $\mathrm{pH}$ in soil suspension 1:2.5 using pH-meter, 3320 Jenway, (Soil Testing Laboratory, 2012); electrical conductivity (ECe) in the soil saturation extract using electrical conductivity meter (YSI model 35).

- Soluble cations and anions according to the standard methods outlined (Haluschak, 2006).

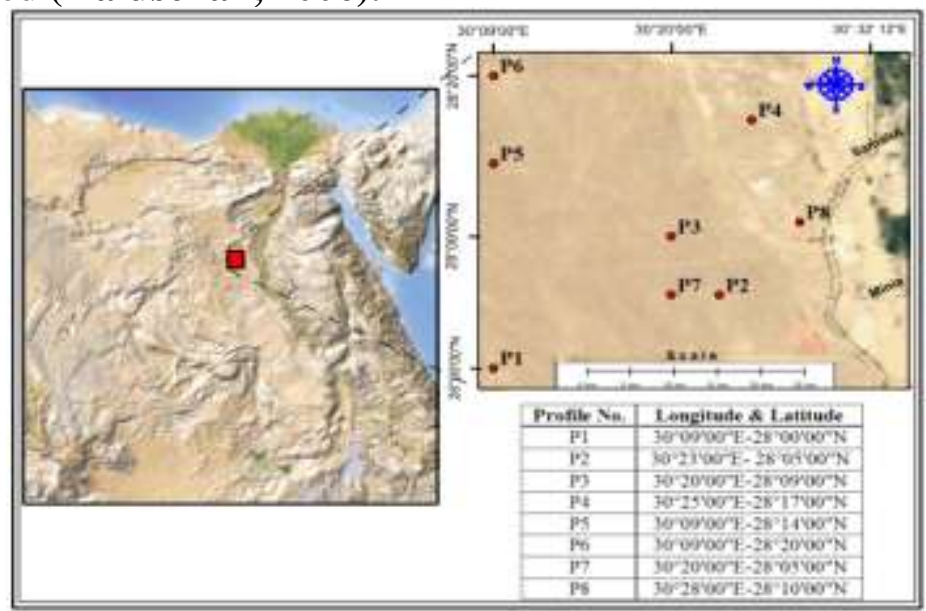

Fig. (1): Location of the studied soil profiles 
Chemically extractable micronutrients $\mathrm{Fe}, \mathrm{Mn}, \mathrm{Zn}, \mathrm{Cu}, \mathrm{Ni}$ and $\mathrm{Cr}$ were determined according to Soltanpour and Schwab (1977) using the extractant of ammonium bicarbonate- diethyl-triamine-penta acetic acid (AB-DTPA) which is a mixture of $1.0 \mathrm{M}$ ammonium bicarbonate (AB) and $0.005 \mathrm{M}$ DTPA and has a $\mathrm{pH}$ of 7.6, and measuring the elements by the Plasma Optical Emission-Mass Spectrometer (POEMSIII)Thermo Jerral Ash.

\section{RESULTS AND DISCUSSION}

Data in Table (1) Showed that content calcium carbonate containing soils were ranged among 10.5 to $17.2 \%$ denote to all the studied soils samples were among the calcareous soils. The soil reactions were detected to be between 6.8 to 7.6 that indicates the neutrality of soil reactions.

The electrical conductivity values of soil past extraction were ranged among 5.6 to $35.6 \mathrm{dS} \mathrm{cm}$ indicate that soil samples were saline to highly saline soils. Also, the values of $\mathrm{Na} \mathrm{mmol}_{\mathrm{c}} \mathrm{L}^{-1}$ were very high that may reflect high risk for pants growth in this area. The lowest values of electrical conductivity were detected is soil samples collected from soil profiles numbers seven and eight.

Table (1): Chemical properties of the studied soils

\begin{tabular}{|c|c|c|c|c|c|c|c|c|c|c|c|c|c|}
\hline \multirow{2}{*}{$\begin{array}{c}\text { Geomorphic } \\
\text { units }\end{array}$} & \multirow{2}{*}{$\begin{array}{c}\text { Profile } \\
\text { No. }\end{array}$} & \multirow{2}{*}{$\begin{array}{l}\text { Depth } \\
,(\mathrm{cm})\end{array}$} & \multirow{2}{*}{$\begin{array}{c}\mathrm{CaCO}_{3} \\
(\%)\end{array}$} & \multirow[t]{2}{*}{ pH } & \multirow{2}{*}{$\begin{array}{c}E C \\
\mathrm{dS} \mathrm{\textrm {cm } ^ { - 1 }}\end{array}$} & \multicolumn{4}{|c|}{ Cations $\operatorname{mmol}_{\mathrm{c}} \mathrm{L}^{-1}$} & \multicolumn{4}{|c|}{ Anions $\operatorname{mmol}_{\mathrm{c}} \mathbf{L}^{-1}$} \\
\hline & & & & & & $\mathrm{Ca}^{++}$ & $\mathrm{Mg}^{++}$ & $\mathrm{Na}^{+}$ & $\mathbf{K}^{+}$ & $\mathrm{CO}_{3}{ }^{=}$ & $\mathrm{HCO}_{3}^{-}$ & $\mathrm{Cl}^{-}$ & $\mathrm{SO}_{4}{ }^{=}$ \\
\hline \multirow{12}{*}{$\begin{array}{l}\text { Medium } \\
\text { high } \\
\text { Terraces }\end{array}$} & \multirow[t]{3}{*}{1} & $0-30$ & 15.2 & 7.3 & 20.5 & 44.05 & 20.0 & 140.0 & 0.95 & 0.0 & 2.5 & 145.0 & 57.5 \\
\hline & & $30-60$ & 16.8 & 7.2 & 30.7 & 56.9 & 13.6 & 235.0 & 1.5 & 0.0 & 15.7 & 220.0 & 71.3 \\
\hline & & $60-100$ & 10.5 & 7.4 & 40.4 & 65.6 & 25.9 & 310.0 & 2.4 & 0.0 & 20.9 & 280.0 & $\mathbf{1 0 3 . 1}$ \\
\hline & \multirow[t]{3}{*}{2} & $0-30$ & 11.7 & 7.1 & 25.9 & 20.7 & 10.5 & 225.0 & 2.8 & 0.0 & 13.5 & 200.0 & 45.5 \\
\hline & & $30-60$ & 10.8 & 7.5 & 18.9 & 25.22 & 22.9 & 140.0 & 0.88 & 0.0 & 3.3 & 140.9 & 44.8 \\
\hline & & 60-100 & 17.3 & 7.4 & 12.4 & 28.1 & 14.5 & 80.4 & 1.0 & 0.0 & 8.5 & 99.0 & 16.5 \\
\hline & \multirow[t]{3}{*}{3} & $0-30$ & 14.9 & 7.2 & 14.5 & 27.65 & 25.5 & 90.9 & 0.95 & 0.0 & 12.8 & 120.0 & 12.2 \\
\hline & & $30-60$ & 19.8 & 7.3 & 16.9 & 22.5 & 19.9 & 125.5 & 1.1 & 0.0 & 5.5 & 165.0 & 13.5 \\
\hline & & $60-100$ & 12.6 & 7.5 & 22.4 & 18.3 & 14.7 & 190.0 & 1.0 & 0.0 & 12.9 & 175.0 & 36.1 \\
\hline & \multirow[t]{3}{*}{4} & $0-30$ & 17.2 & 7.1 & 45.7 & 76.3 & 28.8 & \begin{tabular}{|l|}
350.0 \\
\end{tabular} & 1.9 & 0.0 & 25.9 & 360.0 & 71.1 \\
\hline & & $30-60$ & 11.9 & 6.9 & 31.9 & 38.3 & 18.9 & 260.0 & 1.8 & 0.0 & 19.9 & 230.0 & 69.1 \\
\hline & & $60-100$ & 20.8 & 7.1 & 13.8 & 20.9 & 16.9 & 99.0 & 1.2 & 0.0 & 9.9 & 110.0 & 18.1 \\
\hline \multirow{10}{*}{$\begin{array}{l}\text { Low high } \\
\text { Terraces }\end{array}$} & \multirow[t]{3}{*}{5} & $0-30$ & 11.3 & 7.3 & 24.9 & 42.1 & 9.9 & 195.9 & 1.1 & 0.0 & 11.5 & 175.0 & 62.5 \\
\hline & & $30-60$ & 12.9 & 7.4 & 41.9 & 51.1 & 25.5 & 340.0 & 2.4 & 0.0 & 22.9 & 330.9 & 65.2 \\
\hline & & 60-100 & 10.8 & 6.8 & 25.8 & 26.1 & 9.8 & 220.0 & 2.1 & 0.0 & 12.4 & 185.9 & 59.7 \\
\hline & \multirow[t]{3}{*}{6} & $0-30$ & 15.7 & 7.1 & 8.9 & $\mathbf{1 7 . 5}$ & 14.6 & 55.8 & 1.1 & 0.0 & 5.9 & 65.8 & 17.3 \\
\hline & & $30-60$ & 14.9 & 7.6 & 12.9 & 20.3 & 16.8 & 90.6 & 1.3 & 0.0 & 9.9 & 110.8 & 8.3 \\
\hline & & $60-100$ & 13.8 & 7.4 & 35.6 & 32.6 & 30.8 & 290.0 & 2.6 & 0.0 & 25.9 & 285.0 & 45.1 \\
\hline & \multirow[t]{2}{*}{7} & $0-25$ & 12.2 & 7.1 & 8.5 & 14.5 & 8.9 & 60.8 & 0.80 & 0.0 & 6.6 & 61.7 & 16.7 \\
\hline & & $25-40$ & 15.4 & 7.3 & 5.6 & 3.7 & 2.9 & 48.7 & 0.70 & 0.0 & 2.7 & 48.9 & 4.4 \\
\hline & \multirow[t]{2}{*}{8} & $0-25$ & 11.1 & 7.6 & 9.2 & $\begin{array}{l}.0 \\
\end{array}$ & 20.9 & 77.5 & 0.6 & 0.0 & 12.9 & 70.9 & 8.2 \\
\hline & & $25-40$ & 13.4 & 7.2 & 7.5 & 10.5 & 6.6 & 57.0 & 0.9 & 0.0 & 6.9 & 67.0 & 1.1 \\
\hline
\end{tabular}

Data presented in (Table 2) shows that the particle size distribution and textural classes of the different layers of studied soils profiles. The very course sand percentages (VCS: $2.0-1.0 \mathrm{~mm}$ ) were ranged among $3.9 \%$ to $58 \%$ in the top surface layer of soil profile number four and third 
layer of soil profile number 6 , respectively. The course sand percentages (CS: $1.0-0.5 \mathrm{~mm}$ ) were varied among $3.5 \%$ to $20 \%$ in the first layer of soil profile number six and the second layer of soil profile number seven, respectively. The medium sand percentages (MS: $0.5-0.25 \mathrm{~mm}$ ) were ranged between $18 \%$ to $30.1 \%$ in the second layers of soil profile number two and four, respectively. The fine sand percentages (FS: $0.25-0.125$ $\mathrm{mm}$ ) were oscillated among $19.9 \%$ to $50.1 \%$ in second layer of soil profile number two and the first layer of soil profile number four respectively. The very fine sand percentages (VFS: $0.125-0.063 \mathrm{~mm}$ ) were ranged among $0.5 \%$ to $17.1 \%$ in the third layer of soil profile number two and four, respectively. Finally, the total course sand percentages were ranged between 79.9 to $96.1 \%$ in the first layer of soil profile number three and four, respectively. The soil texture has been oscillated among sand and loamy sand.

Table (2): Particle size distribution and textural classes of the studied

\begin{tabular}{|c|c|c|c|c|c|c|c|c|c|c|}
\hline \multirow{3}{*}{$\begin{array}{l}\text { Geomorphic } \\
\text { units }\end{array}$} & \multirow{3}{*}{$\begin{array}{c}\text { Profile } \\
\text { No. }\end{array}$} & \multirow{3}{*}{ Depth, Cm. } & \multicolumn{5}{|c|}{ Coarse sand \% } & \multirow{3}{*}{$\begin{array}{c}\text { Total } \\
\text { coarse } \\
\text { sand } \%\end{array}$} & \multirow{3}{*}{$\begin{array}{c}\begin{array}{c}\text { Fine } \\
\text { sand \% }\end{array} \\
(\mathbf{S i}+\mathbf{C l}) \\
>0.063 \\
\text { mm }\end{array}$} & \multirow{3}{*}{$\begin{array}{c}\text { Textural } \\
\text { classes }\end{array}$} \\
\hline & & & VCS & CS & MS & FS & VFS & & & \\
\hline & & & $\begin{array}{c}2.0- \\
1.0 \\
\text { mm }\end{array}$ & $\begin{array}{c}1.0- \\
0.5 \\
\mathrm{~mm}\end{array}$ & $\begin{array}{l}0.5- \\
0.25 \\
\mathrm{~mm}\end{array}$ & $\begin{array}{c}0.25- \\
0.125 \\
\text { mm }\end{array}$ & $\begin{array}{c}0.125- \\
0.063 \\
\text { mm }\end{array}$ & & & \\
\hline \multirow{9}{*}{$\begin{array}{c}\text { Medium } \\
\text { high } \\
\text { Terraces }\end{array}$} & \multirow[t]{3}{*}{1} & 0-30 & 8.3 & 10.7 & 19.1 & 26.9 & 15.0 & 80.0 & 20.0 & $\begin{array}{c}\text { Loamy } \\
\text { sand }\end{array}$ \\
\hline & & $30-60$ & 22.3 & 14.2 & 20.4 & 20.1 & 13.1 & 90.1 & 9.9 & sand \\
\hline & & $60-100$ & 20.9 & 13.2 & 20.5 & 21.0 & 6.2 & 81.8 & 18.2 & $\begin{array}{l}\text { Loamy } \\
\text { sand }\end{array}$ \\
\hline & \multirow[t]{3}{*}{2} & 0-30 & 16.7 & 11.1 & 22.5 & 26.0 & 19.2 & 95.5 & 4.5 & sand \\
\hline & & $30-60$ & 26.6 & 12.0 & 18.0 & 19.9 & 11.4 & 87.9 & 12.1 & sand \\
\hline & & $60-100$ & 11.1 & 17.5 & 36.0 & 24.7 & 0.5 & 89.8 & 10.2 & sand \\
\hline & \multirow[t]{3}{*}{3} & 0-30 & 5.4 & 5.1 & 27.8 & 37.1 & 4.5 & 79.9 & 20.1 & $\begin{array}{c}\text { Loamy } \\
\text { sand }\end{array}$ \\
\hline & & $30-60$ & 5.9 & 4.1 & 28.8 & 37.2 & 19.6 & 95.6 & 4.4 & sand \\
\hline & & $60-100$ & 3.9 & 6.4 & 26.0 & 34.2 & 10.6 & 81.1 & 18.9 & $\begin{array}{c}\text { Loamy } \\
\text { sand }\end{array}$ \\
\hline \multirow{13}{*}{$\begin{array}{c}\text { Low high } \\
\text { Terraces }\end{array}$} & \multirow[t]{3}{*}{4} & 0-30 & 3.9 & 4.1 & 28.1 & 50.1 & 9.9 & 96.1 & 3.9 & sand \\
\hline & & $30-60$ & 16.0 & 20.8 & 30.1 & 23.4 & 2.1 & 92.4 & 7.6 & sand \\
\hline & & $60-100$ & 5.7 & 4.3 & 31.4 & 36.1 & 17.1 & 94.6 & 5.4 & sand \\
\hline & \multirow[t]{3}{*}{5} & $0-30$ & 5.5 & 5.0 & 23.6 & 39.7 & 13.6 & 87.4 & 12.6 & sand \\
\hline & & $30-60$ & 8.0 & 4.3 & 27.9 & 36.4 & 15.3 & 91.9 & 8.1 & sand \\
\hline & & $60-100$ & 15.5 & 9.9 & 20.9 & 29.3 & 10.3 & 85.9 & 14.1 & $\begin{array}{c}\text { Loamy } \\
\text { sand }\end{array}$ \\
\hline & \multirow[t]{3}{*}{6} & $0-30$ & 7.5 & 3.5 & 26.8 & 42.6 & 16.6 & 97.0 & 3.0 & sand \\
\hline & & $30-60$ & 10.2 & 4.5 & 21.8 & 33.4 & 16.2 & 86.1 & 13.9 & sand \\
\hline & & $60-100$ & 58.0 & 6.7 & 20.9 & 40.3 & 10.9 & 95.0 & 5.0 & sand \\
\hline & \multirow[t]{2}{*}{7} & $0-25$ & 9.6 & 12.3 & 23.4 & 29.8 & 7.0 & 82.1 & 17.9 & $\begin{array}{c}\text { Loamy } \\
\text { sand }\end{array}$ \\
\hline & & $25-40$ & 13.5 & 20.8 & 25.6 & 26.6 & 10.0 & 96.5 & 3.5 & sand \\
\hline & \multirow[t]{2}{*}{8} & $0-25$ & 12.7 & 12.8 & 22.2 & 27.4 & 6.2 & 81.3 & 18.7 & $\begin{array}{c}\text { Loamy } \\
\text { sand }\end{array}$ \\
\hline & & $25-40$ & 5.8 & 5.7 & 25.5 & 45.6 & 13.6 & 96.2 & 3.8 & sand \\
\hline
\end{tabular}

Note. VCS: Very coarse sand, CS: Coarse sand, MS: Medium sand, FS: Fine sand, VFS: Very fine sand and $(\mathrm{Si}+\mathrm{Cl})$ silt + Clay. 
Data presented in (Table 3) listed the vertical distribution of available $\mathrm{Fe}, \mathrm{Mn}, \mathrm{Zn}, \mathrm{Cu}, \mathrm{Ni}$, and $\mathrm{Cr}$ in the studied soil profiles. It was clear notice that, the vertical distribution of available Fe was oscillated among the geomorphic units including medium high terraces and low high terraces. In the first three profiles that belongs to medium high terraces, $\mathrm{Fe}$ concentrations were increased with increasing soil profile depth particularly with the third layer that exist among $60-100 \mathrm{~cm}$. On the other hand, the four soil profiles (4-6) that belongs to low high terraces, Fe concentrations were decreased that presented the opposite tendency that was observed with soil profiles (1-3). For soil profiles number seven and eight it was observed the parallel behavior that was obtained previously with the studied soil profiles number (1-3). The highest values of Fe was found in the second layer of soil profile number eight to be $25.80 \mathrm{mg} \mathrm{kg}^{-1}$, however the lowest values were found in the first layer of soil profile number 1 to be $1.50 \mathrm{mg} \mathrm{kg}^{-1}$. The concentrations of available Fe was higher than the critical levels of 2.5-2.6 $\mathrm{mg} \mathrm{kg}^{-1}$ except for the first layer of soil profile number one (Esmail and Sharef, 2017).

Table (3): Chemically extractable micronutrients of the studied soils

\begin{tabular}{|c|c|c|c|c|c|c|c|c|}
\hline \multirow{2}{*}{$\begin{array}{l}\text { Geomorphic } \\
\text { units }\end{array}$} & \multirow{2}{*}{$\begin{array}{l}\text { Profile } \\
\text { No. }\end{array}$} & \multirow{2}{*}{$\begin{array}{l}\text { Depth, } \\
\text { Cm. }\end{array}$} & \multicolumn{6}{|c|}{ Available micronutrients $\mathrm{mg} \mathrm{Kg}^{-1}$} \\
\hline & & & $\mathbf{F e}$ & Mn & Zn & $\mathbf{C u}$ & $\mathbf{N i}$ & $\mathbf{C r}$ \\
\hline \multirow{9}{*}{ 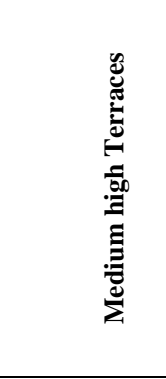 } & \multirow[t]{3}{*}{1} & 0-30 & 1.50 & 0.10 & 0.99 & 0.50 & 1.00 & 1.99 \\
\hline & & $30-60$ & 3.40 & 0.80 & 0.6 & 0.80 & 1.12 & 1.70 \\
\hline & & $60-100$ & 3.8 & 0.65 & 0.66 & 0.44 & 2.10 & 1.80 \\
\hline & \multirow[t]{3}{*}{2} & 0-30 & 3.5 & 0.37 & 0.76 & 0.34 & 2.40 & 1.60 \\
\hline & & $30-60$ & 3.1 & 0.76 & 0.60 & 0.11 & 0.99 & 1.90 \\
\hline & & $60-100$ & 4.00 & 0.89 & 0.76 & 0.15 & 0.85 & 1.70 \\
\hline & \multirow[t]{3}{*}{3} & 0-30 & 5.1 & 2.7 & 0.30 & 0.60 & 0.92 & 1.50 \\
\hline & & $30-60$ & 6.8 & 2.9 & 0.88 & 0.15 & 2.70 & 1.40 \\
\hline & & $60-100$ & 5.50 & 3.30 & 0.99 & 0.16 & 2.99 & 1.30 \\
\hline \multirow{13}{*}{ 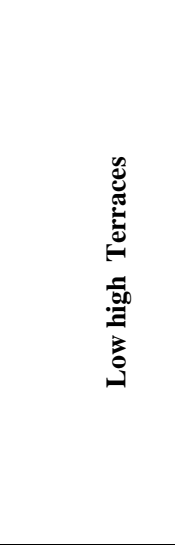 } & \multirow[t]{3}{*}{4} & $0-30$ & 9.88 & 3.40 & 0.78 & 0.80 & 3.11 & 1.90 \\
\hline & & $30-60$ & 8.90 & 0.90 & 0.45 & 0.66 & 3.00 & 2.00 \\
\hline & & $60-100$ & 7.90 & 1.30 & 0.90 & 0.70 & 2.77 & 2.11 \\
\hline & \multirow[t]{3}{*}{5} & $0-30$ & 8.90 & 1.20 & 1.90 & 0.60 & 2.50 & 1.90 \\
\hline & & $30-60$ & 5.60 & 1.60 & 1.32 & 0.70 & 2.45 & 1.80 \\
\hline & & $60-100$ & 4.50 & 1.70 & 1.22 & 0.80 & 2.22 & 2.00 \\
\hline & \multirow[t]{3}{*}{6} & $\mathbf{0 - 3 0}$ & 20.00 & 1.88 & 1.00 & 0.60 & 1.99 & 2.45 \\
\hline & & $30-60$ & 17.80 & 1.20 & 0.88 & 0.77 & 2.88 & 2.11 \\
\hline & & $60-100$ & 15.77 & 1.33 & 0.98 & 0.34 & 1.90 & 1.80 \\
\hline & \multirow[t]{2}{*}{7} & $0-25$ & 19.11 & 1.90 & 0.61 & 0.21 & 2.55 & 1.70 \\
\hline & & $25-40$ & 22.10 & 1.87 & 0.74 & 0.80 & 3.10 & 1.43 \\
\hline & \multirow[t]{2}{*}{8} & $0-25$ & 23.67 & 1.95 & 0.80 & 0.33 & 3.20 & 1.35 \\
\hline & & $25-40$ & 25.80 & 1.30 & 0.45 & 0.45 & 3.22 & 1.20 \\
\hline
\end{tabular}


The distribution of available Mn was also oscillated within the different depths. For the first three soil profiles Mn concentrations were increased with increasing soil depth. The same tendency that was observed with Fe for the rest 4-8 was also observed with Mn in which Mn concertation was decreased with increasing soil depth for the studied soil profiles numbers (4-6). However, soil profiles numbers seven and eight showed the same tendency that was observed with soil profiles numbers one, two, and three. The highest values of $\mathrm{Mn}$ was observed to be $3.3 \mathrm{mg} \mathrm{kg}^{-1}$ in the third layer of soil profile number 3 . However, the lowest values of Mn was observed in the first layer of soil profile number one. The Critical values of $\mathrm{Mn}$ in both sandy and calcareous soils were set to be 1.4 and $1.2 \mathrm{ug} \mathrm{g}^{-1}$, respectively. Accordingly, the concentrations of $\mathrm{Mn}$ in the studied soils were lower that the critical levels particularly for soil profiles number one and two. On the other hand, it was close to the critical levels in the rest of soil samples. Comparatively, high levels of Mn were observed with the deep layer of soil profile number three and the top layer of soil profile number four (Elgala et al., 1986).

The distribution of available $\mathrm{Zn}$ in the studied soil profiles was oscillated with increasing soil depth. The concentrations of available $\mathrm{Zn}$ tended to decrease with soil profiles numbers one, two, five, six, and eight. However, for soil profiles numbers three and four $\mathrm{Mn}$ concentrations tended to be increased. The highest values of available $\mathrm{Zn}$ was found in the first layer of soil profile number five that was equal to $1.9 \mathrm{mg} \mathrm{kg}^{-1}$. On the other hand, the lowest values of available $\mathrm{Zn}$ were observed in the second layer of soil profiles number four and eight, respectively. As it has been set previously by other study the critical levels of $\mathrm{Zn}$ in the alluvial and calcareous soils were 0.9 and $0.7 \mathrm{ug} \mathrm{g}^{-1}$, respectively. The soil samples that are collected from soil profiles 1-4 were lower than or equal to the critical levels (Elgala et al., 1986).

The vertical distribution of $\mathrm{Cu}$ is listed in Table 3. The concentrations of $\mathrm{Cu}$ were increased with increasing soil depth for soil profiles numbers one, five, six, seven, and eight. However, the opposite tendency was observed with soil profiles numbers two, three, and four. The highest values of $\mathrm{Cu}$ was observed in the first layer of soil profile number one, the third layer of profile number five, and the second layer of soil profile seven that was equal to $0.80 \mathrm{mg} \mathrm{kg} \mathrm{kg}$. However, the lowest values of $\mathrm{Cu}$ was observed in the second layer of soil profile number two that was equal to $0.11 \mathrm{mg} \mathrm{kg}^{-1}$. The critical levels of $\mathrm{Cu}$ in soil was set to be low if it ranged among $0-0.05 \mathrm{mg} \mathrm{kg}^{-1}$, and high if it higher than $0.5 \mathrm{mg} \mathrm{kg}^{-1}$, the $\mathrm{Cu}$ levels in our study were oscillated among the high and medium levels . 
Table (4): Weighted mean, trend, and specific ranges of available $\mathrm{Fe}, \mathrm{Mn}, \mathrm{Zn}, \mathrm{Cu}, \mathrm{Ni}$ and $\mathrm{Cr}$ of the studied soils

\begin{tabular}{|c|c|c|c|c|c|c|c|c|c|c|c|c|c|c|c|c|c|c|}
\hline \multirow{2}{*}{$\begin{array}{c}\text { Profile } \\
\text { No. }\end{array}$} & \multicolumn{3}{|c|}{$\mathbf{F e}$} & \multicolumn{3}{|c|}{ Mn } & \multicolumn{3}{|c|}{$\mathbf{Z n}$} & \multicolumn{3}{|c|}{$\mathrm{Cu}$} & \multicolumn{3}{|c|}{$\mathbf{N i}$} & \multicolumn{3}{|c|}{$\mathrm{Cr}$} \\
\hline & W & $\mathbf{T}$ & $\mathbf{R}$ & W & $\mathbf{T}$ & $\mathbf{R}$ & W & $\mathbf{T}$ & $\mathbf{R}$ & W & $\mathbf{T}$ & $\mathbf{R}$ & W & $\mathbf{T}$ & $\mathbf{R}$ & W & $\mathbf{T}$ & $\mathbf{R}$ \\
\hline 1 & 2.99 & +0.50 & 0.77 & 0.53 & +0.81 & 1.32 & 0.74 & -0.25 & 0.53 & 0.57 & +0.12 & 0.64 & 1.48 & +0.32 & 0.75 & 1.83 & -0.08 & 0.16 \\
\hline 2 & 3.58 & +0.02 & 0.25 & 0.70 & +0.47 & 0.75 & 0.71 & -0.06 & 0.22 & 0.20 & -0.44 & 1.18 & 1.36 & -0.43 & 1.14 & 1.73 & +0.08 & 0.17 \\
\hline 3 & 5.77 & -0.15 & 0.29 & 3.00 & +0.10 & 0.20 & 0.75 & +0.60 & 0.92 & 0.29 & -0.52 & 1.56 & 2.28 & +0.60 & 0.91 & 1.39 & -0.07 & 0.14 \\
\hline 4 & 8.79 & -0.11 & 0.23 & 1.81 & -0.47 & 1.38 & 0.73 & -0.07 & 0.62 & 0.72 & -0.10 & 0.19 & 2.94 & -0.05 & 0.12 & 2.01 & +0.06 & 0.10 \\
\hline 5 & 6.15 & -0.31 & 0.72 & 1.52 & +0.21 & 0.33 & 1.45 & -0.24 & 0.47 & 0.71 & +0.15 & 0.28 & 2.37 & -0.05 & 0.12 & 1.91 & +0.01 & 0.10 \\
\hline 6 & 17.65 & -0.12 & 0.24 & 1.46 & -0.23 & 0.47 & 0.96 & -0.04 & 0.13 & 0.55 & -0.09 & 0.79 & 2.22 & +0.10 & 0.44 & 2.09 & -0.15 & 0.31 \\
\hline 7 & 20.23 & -0.06 & 0.15 & 1.89 & -0.01 & 0.02 & 0.66 & +0.07 & 0.20 & 0.43 & +0.51 & 1.37 & 2.76 & +0.07 & 0.20 & 1.60 & -0.06 & 0.17 \\
\hline 8 & 24.47 & +0.03 & 0.09 & 1.71 & -0.13 & 0.38 & 0.67 & -0.16 & 0.52 & 0.38 & +0.12 & 0.32 & 3.21 & 0.0 & 0.01 & 1.29 & -0.04 & 0.12 \\
\hline
\end{tabular}


The distribution of available $\mathrm{Ni}$ in the studied soil profiled is also presented in Table 3. It was clear seen that the concentrations of available $\mathrm{Ni}$ were tended to increase with soil depth for all soil profiles except for soil profiles number two and four. The highest values of $\mathrm{Ni}$ were found to be $3.22 \mathrm{mg} \mathrm{kg}^{-1}$ in the second layer for soil profile number eight, however the lowest values were found to be $1.0 \mathrm{mg} \mathrm{kg}^{-1}$ and were observed in the first of soil profile number one. The distribution of $\mathrm{Cr}$ tended to decrease with increasing soil depth for all soil profiles except for soil profiles number two and five. The highest values of $\mathrm{Cr}$ were found to be $2.45 \mathrm{mg} \mathrm{kg}^{-1}$ and were observed in the first layer of soil profile number six, however the lowest values were observed in the first layer of soil profile number eight to $1.35 \mathrm{mg} \mathrm{kg}^{-1}$.

Data presented in Table 4 shows the vertical values of weighted mean, trend, and specific ranges of available $\mathrm{Fe}, \mathrm{Mn}, \mathrm{Zn}, \mathrm{Cu}, \mathrm{Ni}$ and $\mathrm{Cr}$ in the studied soils profiles. The weighted means of $\mathrm{Fe}$ were ranged among 2.99 to 24.47 in the first and eight soil profiles, respectively. The order of sequence for the studied soil profiles was as follows: soil profile number $8>$ soil profile number $7>$ soil profile number $6>$ soil profile number $5>$ soil profile number $4>$ soil profile number $3>$ soil profile number $2>$ soil profile number 1 . The range values were oscillated among positively and negatively values. The negatively values were obtained with soil profiles numbers one, two, three, seven, and eight, respectively. However, the positive values were obtained with soil profiles numbers four, five, and six. The ratio values were ranged among 0.09 and 0.77 in soil profiles numbers eight and one, respectively. The sequence of order of ratio values of the studied soil profiles were found to take the following order soil profile number $8<$ soil profile number 7 $<$ soil profile number $4<$ soil profile number $6<$ soil profile number < soil profile number $3<$ soil profile number $5<$ soil profile number 1 . The weighted means of $\mathrm{Mn}$ were ranged among 0.53 to 3.0 in the first and third soil profiles, respectively. The order of sequence for the studied soil profiles was soil profile $1>$ soil profile number $2>$ soil profile number 6 $>$ soil profile number $5>$ soil profile number $8>$ soil profile number $4>$ soil profile number $7>$ soil profile number 3 . The range values were oscillated among positively and negatively values. The negatively values were obtained with soil profiles numbers one, two, three, and five, respectively. However, the positive values were obtained with soil profiles numbers four, seven, six, and eight. The ratio values were ranged among 0.02 and 1.38 in soil profiles numbers seven and four 
respectively. The sequence of order of ratio values of the studied soil profiles were found to take the following order soil profile number $7<$ soil profile number $3<$ soil profile number $5<$ soil profile number $8<$ soil profile number $6<$ soil profile number $2<$ soil profile number $1<$ soil profile number 4 .

The weighted means of $\mathrm{Zn}$ were ranged among 0.66 to 1.45 in the seventh and fifth soil profiles, respectively. The order of sequence for the studied soil profiles was soil profile number $8<$ soil profile number $7<$ soil profile number $4<$ soil profile number $2<$ soil profile number $3<$ soil profile number $1<$ soil profile number $6<$ soil profile number 5 . The range values were oscillated among positively and negatively values. The negatively values were obtained with soil profiles numbers three, and seven, respectively. However, the positive values were obtained with soil profiles numbers one, two, four, five, six, and eight. The ratio values were ranged among 0.13 and 0.92 in soil profiles numbers 6 and 3, respectively. The sequence of order of ratio values of the studied soil profiles were found to take the following order soil profile number $6<$ soil profile number $7<$ soil profile number $2<$ soil profile number $5<$ soil profile number $4<$ soil profile number $1<$ soil profile number $8<$ soil profile number 3 . The weighted means of $\mathrm{Cu}$ were ranged among 0.20 to 0.72 in the second and forth soil profiles, respectively. The order of sequence for the studied soil profiles was soil profile number $2<$ soil profile number $3<$ soil profile number $8<$ soil profile number $7<$ soil profile number $6<$ soil profile number $1<$ soil profile number $4<$ soil profile number 4 . The range values were oscillated among positively and negatively values. The negatively values were obtained with soil profiles numbers five, seven, and eight, respectively. However, the positively values were obtained with soil profiles numbers one, two, three, four, and six. The ratio values were ranged among 0.19 and 1.56 in soil profiles numbers four and three, respectively. The sequence of order of ratio values of the studied soil profiles were found to take the following order soil profile number $4<$ soil profile number $5<$ soil profile number $8<$ soil profile number $1<$ soil profile number $6<$ soil profile number $2<$ soil profile number $3<$ soil profile number 7 .

The weighted means of $\mathrm{Ni}$ were ranged among 1.48 to 3.21 in the first and eighth soil profiles, respectively. The order of sequence for the studied soil profiles was soil profile number $2<$ soil profile number $1<$ soil profile number $6<$ soil profile number $3<$ soil profile number $5<$ soil profile number $7<$ soil profile number $4<$ soil profile number 8 . 
The range values were oscillated among positively and negatively values. The negative values were obtained with soil profiles numbers one, three, six and seven, respectively. However, the positively values were obtained with soil profiles numbers two, four, five and eight. The ratio values were ranged among 0.01 and 1.14 in soil profiles numbers eight and two respectively. The sequence of order of ratio values of the studied soil profiles were found to take the following order soil profile number $8<$ soil profile number $4=$ soil profile number $5<$ soil profile number $7<$ soil profile number $6<$ soil profile number $3<$ soil profile number $1<$ soil profile number 2 . The weighted means of $\mathrm{Cr}$ were ranged among 1.29 to 2.09 in the eighth and sixth soil profiles, respectively. The order of sequence for the studied soil profiles was soil profile number $8<$ soil profile number $3<$ soil profile number $7<$ soil profile number $2<$ soil profile number $5<$ soil profile number $1<$ soil profile number $4<$ soil profile number 6 .

The range values were oscillated among positively and negatively values. The negative values were obtained with soil profiles numbers two, four and five, respectively. However, the positive values were obtained with soil profiles numbers one, three, six, seven, and eight. The ratio values were ranged among 0.10 and 0.31 in soil profiles numbers (4 and 5) and 6 respectively. The sequence of order of ratio values of the studied soil profiles were found to take the following order soil profile number $4=$ soil profile number $5<$ soil profile number $8<$ soil profile number $3<$ soil profile number $1<$ soil profile number $2=$ soil profile number $7<$ soil profile number 6 .

\section{Correlation between available heavy metals and soil chemical properties}

The correlation between the studied heavy metals and soil chemical properties is presented in Table (5). The effect of $\mathrm{Ca} \mathrm{CO}_{3}$ content was found to oscillate among the positively and negatively correlations. The correlations were positively with $\mathrm{Mn}, \mathrm{Cu}$, and $\mathrm{Cr}$, however $\mathrm{Fe}, \mathrm{Zn}$, and $\mathrm{Ni}$ were correlated negatively. The highest values of correlation were found to be 0.25 with $\mathrm{Zn}$, however the lowest values were found with $\mathrm{Zn}$ to be -0.11 . The effect of $\mathrm{pH}$ was found to correlate negatively with all studied heavy metals except for $\mathrm{Fe}$ and $\mathrm{Zn}$. The highest values of correlations was found with Fe to be 0.12 , however the lowest values of correlation was found with $\mathrm{Cr}$ to be -0.30 . The effects of salts concentrations $\left(\mathrm{dS} \mathrm{cm}^{-1}\right)$ on the studied heavy metals were found to oscillate among the negatively and positively correlations. The electrical 
conductively presented negatively correlations with $\mathrm{Fe}, \mathrm{Mn}$, and $\mathrm{Ni}$, however it was correlated positively with $\mathrm{Zn}, \mathrm{Cu}$, and $\mathrm{Cr}$. The highest values of correlations were found with $\mathrm{Cu}$ to be 0.24 , however the lowest values were found with $\mathrm{Fe}$ to be -0.52 . The effects of $\mathrm{Ca}^{2+}$ concentration in the extractable soil past $\left(\mathrm{mmol}_{\mathrm{c}} \mathrm{L}^{-1}\right)$ were found to oscillate among the negatively and positively correlations. Calcium concentrations were correlated negatively with $\mathrm{Fe}, \mathrm{Mn}$, and $\mathrm{Ni}$ similar to the effects of electrical conductively. However, it was correlated positively with $\mathrm{Zn}$, $\mathrm{Cu}$, and $\mathrm{Cr}$. The highest values of correlations were observed with $\mathrm{Cu}$ to be 0.32 , however the lowest values were found with Fe to be -0.55 .

The majority of heavy metals were correlated negatively with $\mathrm{Mg}$ concentrations $\left(\mathrm{mmol}_{\mathrm{c}} \mathrm{L}^{-1}\right)$ except for $\mathrm{Mn}$ and $\mathrm{Cr}$. The highest values of correlations were found with $\mathrm{Mn}$ to be 0.14 , however the lowest values were found with $\mathrm{Fe}$ to be -0.31 . In contrast, the majority of heavy metals were correlated positively with $\mathrm{Na}$ concentrations $\left(\mathrm{mmol}_{\mathrm{c}} \mathrm{L}^{-1}\right)$ except for $\mathrm{Fe}$ and $\mathrm{Mn}$. The highest values of correlations were found with $\mathrm{Zn}$ to be 0.24 , however the lowest values were found to be -0.49 . The effect of $\mathrm{k}$ concentrations $\left(\mathrm{mmol}_{\mathrm{c}} \mathrm{L}^{-1}\right)$ were found to be similar to the effects of $\mathrm{Na}$. The highest values of correlations were found with $\mathrm{Cr}$ to be 0.23 , however the lowest values were found with $\mathrm{Fe}$ to be -0.36 . On the hand, the effects of $\mathrm{HCO}_{3}$ and $\mathrm{Cl}$ were almost the same in which the majority of heavy metals were correlated positively except for Fe. The heights values of correlations were found to be 0.27 and 0.22 for $\mathrm{HCO}_{3}$ and $\mathrm{Cl}$, respectively, however, the lowest values were found to be -.017 and 0.49 , respectively. Regarding the effects of $\mathrm{SO}_{4}\left(\mathrm{mmol}_{\mathrm{c}} \mathrm{L}^{-1}\right)$ it was found that $\mathrm{Fe}, \mathrm{Mn}$, and $\mathrm{Ni}$ were correlated negatively, however the rest of heavy metals were correlated positively.

The effects of soil chemical properties on available Fe levels from the correlation point of view were found to take the following sequence $\mathrm{SO}_{4}<\mathrm{Ca}<\mathrm{Ec}<\mathrm{Na}=\mathrm{Cl}<\mathrm{K}<\mathrm{Mg}<\mathrm{HCO}_{3}<\mathrm{CaCO}_{3}<\mathrm{pH}$. However the following sequence was found with $\mathrm{Mn} ; \mathrm{SO}_{4}<\mathrm{K}<\mathrm{Ca}<\mathrm{Ec}=\mathrm{Na}<$ $\mathrm{pH}<\mathrm{Cl}<\mathrm{Mg}=\mathrm{HCO}_{3}<\mathrm{CaCO}_{3}$. On the other hand, the following trend was observed with $\mathrm{Zn} ; \mathrm{CaCO}_{3}<\mathrm{Mg}<\mathrm{HCO}_{3}<\mathrm{pH}<\mathrm{Ca}<\mathrm{K}<\mathrm{Cl}=\mathrm{Ec}<$ $\mathrm{SO}_{4}<\mathrm{Na}$. The effects of soil chemical properties of available $\mathrm{Cu}^{2+}(\mathrm{mg}$ $\mathrm{kg}^{-1}$ ) were found to take the following order; $\mathrm{H}<\mathrm{Mg}<\mathrm{CaCO}_{3}<\mathrm{K}<\mathrm{Cl}$ $<\mathrm{SO}_{4}=\mathrm{Na}<\mathrm{Ec}<\mathrm{HCO}_{3}<\mathrm{Ca}$. Regarding the available Ni the following order was observed $\mathrm{Mg}<\mathrm{Ca}<\mathrm{SO}_{4}<\mathrm{CaCO}_{3}=\mathrm{pH}<\mathrm{Ec}<\mathrm{Cl}<\mathrm{K}<\mathrm{Na}<$ $<\mathrm{HCO}_{3}$. Finally, the effects of soil chemical properties were taken the following order $\mathrm{pH}<\mathrm{HCO}_{3}<\mathrm{CaCO}_{3}<\mathrm{Cl}=\mathrm{Na}<\mathrm{Mg}<\mathrm{Ec}<\mathrm{K}<\mathrm{Ca}<$ $\mathrm{SO}_{4}$. 
Table ( 5): Correlation between elements and soil chemical properties in soils

\begin{tabular}{|c|c|c|c|c|c|c|c|c|c|c|}
\hline Elements & $\mathrm{CaCO}_{3}$ & $\mathrm{pH}$ & $\mathrm{ECe}$ & $\mathrm{Ca}$ & $\mathrm{Mg}$ & $\mathrm{Na}$ & $\mathrm{K}$ & $\mathrm{HCO}_{3}$ & $\mathrm{Cl}$ & $\mathrm{SO}_{4}$ \\
\hline $\mathrm{Fe}$ & -0.04 & 0.12 & -0.52 & -0.55 & -0.31 & -0.49 & -0.36 & -0.17 & -0.49 & -0.61 \\
\hline $\mathrm{Mn}$ & 0.25 & -0.01 & -0.03 & -0.09 & 0.14 & -0.03 & -0.23 & 0.14 & 0.05 & -0.29 \\
\hline $\mathrm{Zn}$ & -0.11 & 0.09 & 0.21 & 0.13 & -0.09 & 0.24 & 0.15 & 0.07 & 0.21 & 0.23 \\
\hline $\mathrm{Cu}$ & 0.17 & -0.40 & 0.24 & 0.32 & -0.08 & 0.23 & 0.21 & 0.27 & 0.22 & 0.23 \\
\hline $\mathrm{Ni}$ & -0.07 & -0.07 & -0.04 & -0.24 & -0.25 & 0.03 & 0.02 & 0.16 & 0.00 & -0.19 \\
\hline $\mathrm{Cr}$ & 0.10 & -0.30 & 0.20 & 0.31 & 0.19 & 0.16 & 0.23 & 0.08 & 0.16 & 0.32 \\
\hline
\end{tabular}




\section{Correlation between elements and soil physical properties}

Data presented in Table (6) shows the correlation between the studied heavy metals and soil physical properties such as soil texture including very coarse sand (VCs) 2.0-1.0 mm, coarse sand (Cs) 1.0-0.5 mm, medium sand (Ms) $0.5-0.25 \mathrm{~mm}$, fine sand (Fs), and very fine sand (VFs) $0.125-0.063$ $\mathrm{mm}$. The correlations between soil texture and Fe distribution were equal zero with VCs and MS. The correlations showed the negatively values with $\mathrm{Cs}$, VFs, and $(\mathrm{Si}+\mathrm{Cl})$, however it were correlated positively with $\mathrm{Fs}$ and total sand \%. The highest values of correlation were obtained with Fs to be 0.38 , however the lowest values were found with $(\mathrm{Si}+\mathrm{Cl})-0.25$. The order of correlations were found to take the following sequence $(\mathrm{Si}+\mathrm{Cl})<\mathrm{Cs}<$ VFs $<$ VCs $=$ Ms $<$ total sand $<$ Fs. The effects of soil texture of the studied samples on Mn distribution were oscillated among the positively and negatively correlations. The distribution of $\mathrm{Mn}$ in the studied soil profiles were negatively correlated with $\mathrm{VCs}, \mathrm{Cs}$, VFs, and $(\mathrm{Si}+\mathrm{Cl})$. However, it was correlated positively with Ms, Fs, total sand. The highest values of correlations were observed with Fs, however the lowest values were observed with Cs. The order of correlation for the distributed of available $\mathrm{Mn}$ inside soil profiles was found to take the following order $\mathrm{Cs}<\mathrm{VCs}<$ VFs $<(\mathrm{Si}-\mathrm{Cl})<$ total sand $<\mathrm{Ms}<\mathrm{Fs}$.

Vertical distributions of $\mathrm{Zn}$ in the studied soil profiles were oscillated also among the positively and negatively correlations. It was correlated negatively with $\mathrm{VCs}, \mathrm{Cs}, \mathrm{Ms}$, and $(\mathrm{Si}+\mathrm{Cl})$, however it were correlated positively with Fs, VFs, and total sand. The highest values of correlation were observed with VFs, however the lowest values were observed with Cs. The sequences of correlation for $\mathrm{Zn}\left(\mathrm{mg} \mathrm{kg}^{-1}\right)$ was found to take the following order $\mathrm{Cs}<\mathrm{Ms}<\mathrm{VCs}<(\mathrm{Si}+\mathrm{Cl})<$ total sand $<\mathrm{Fs}<$ VFs. The vertical distribution of $\mathrm{Cu}$ in the studied soil profiles was found to be correlated negatively with the higher size soil particles such as VCs, Cs, and Ms. Also, $\mathrm{Cu}$ distribution was correlated negatively with $(\mathrm{Si}+\mathrm{Cl})$, however it was correlated positively with Fs, VFs, and total sand. The highest value of correlations was obtained with total sand to be 0.22 , however the lowest values were observed with $(\mathrm{Si}+\mathrm{Cl})$. The order of correlations for $\mathrm{Cu}$ distributions were found to take the following sequence $(\mathrm{Si}+\mathrm{Cl})<\mathrm{VCs}<\mathrm{Cs}=\mathrm{Ms}<\mathrm{VFs}<\mathrm{Fs}<$ total sand.

The vertical distribution of $\mathrm{Ni}$ in the studied soil profiles was oscillated also among the positively and negatively correlations. It was correlated negatively with $\mathrm{VCs}, \mathrm{Cs}$, and $(\mathrm{Si}+\mathrm{Cl})$, however it was correlated positively with Ms, Fs, VFs, and total sand. The highest values of correlation was observed with Fs, however the lowest values were observed with $(\mathrm{Si}+\mathrm{Cl})$. The sequences of correlation for the available concentrations of $\mathrm{Ni}\left(\mathrm{mg} \mathrm{kg}^{-1}\right)$ was found to take the following order $(\mathrm{Si}+\mathrm{Cl})<\mathrm{VCs}<\mathrm{Cs}$ $<$ Ms $<$ VFs $<$ total sand $<$ Fs. 
Table (6) Correlation between heavy metals and soil physical properties

\begin{tabular}{|c|c|c|c|c|c|c|c|}
\hline Elements & $\begin{array}{c}\text { VCs } \\
(2.0-1.0 \\
\text { mm) }\end{array}$ & $\begin{array}{c}\text { Cs } \\
(1.0-0.5 \\
\mathbf{m m}) \\
\end{array}$ & $\begin{array}{c}\text { Ms } \\
(0.5-0.25 \\
\text { mm }) \\
\end{array}$ & $\begin{array}{c}\text { Fs } \\
(0.25-0.125 \\
\text { mm) }\end{array}$ & $\begin{array}{c}\text { VFs } \\
(0.125-0.063 \\
\text { mm) } \\
\end{array}$ & $\begin{array}{c}\text { Total } \\
\text { sand } \\
(\%)\end{array}$ & $\begin{array}{c}(\mathbf{S i}+\mathbf{C l}) \\
(\%)\end{array}$ \\
\hline Fe & 0.00 & -0.03 & 0.00 & 0.38 & -0.01 & 0.25 & -0.25 \\
\hline Mn & -0.36 & -0.42 & 0.35 & 0.58 & -0.05 & 0.03 & -0.03 \\
\hline $\mathbf{Z n}$ & -0.08 & -0.38 & -0.09 & 0.27 & 0.39 & 0.02 & -0.02 \\
\hline $\mathbf{C u}$ & -0.16 & -0.07 & -0.07 & 0.19 & 0.13 & 0.22 & -0.22 \\
\hline $\mathbf{N i}$ & -0.28 & -0.13 & 0.16 & 0.39 & 0.17 & 0.30 & -0.30 \\
\hline $\mathbf{C r}$ & 0.08 & -0.15 & -0.05 & 0.03 & 0.12 & 0.12 & -0.12 \\
\hline
\end{tabular}

The vertical distributions of $\mathrm{Cr}$ in the studied soil profiles was found were oscillated among the positively and negatively correlations. It was correlated positively with $\mathrm{Cs}$, $\mathrm{Ms}$, and $(\mathrm{Si}+\mathrm{Cl})$, however it was correlated positively with VCs, Fs, VFs, and total sand. The highest values of correlations was obtained with VFs and total sand to be 0.12 , however the lowest values were observed with Cs to be -0.15 . The order of correlations for $\mathrm{Cu}$ distributions were found to take the following sequence $(\mathrm{Si}+\mathrm{Cl})<\mathrm{Cs}<\mathrm{Ms}<\mathrm{Fs}<\mathrm{VCs}<\mathrm{VFs}=$ total sand.

\section{CONCLUSION}

The present work is focused on the distribution of some heavy metals containing new reclaimed soils located in Far-West of El-Minya Egypt, in which eight soils profiles were collected in different locations at. In this area, one of the huge national projects that the Egyptian governments. The obtained results showed that, the levels of available $\mathrm{Fe}, \mathrm{Mn}, \mathrm{Zn}, \mathrm{Cu}, \mathrm{Ni}$, and $\mathrm{Cr}$ were oscillated closely to the critical levels of international regulation. The correction between the studied heavy metals and both soil physical and chemical properties tended to be oscillated from element to another. The concentrations of available $\mathrm{Fe}$ was higher than the critical levels of 2.5-2.6 mg kg-1 except for the first layer of soil profile number 1 . The Critical values of $\mathrm{Mn}$ in both sandy and calcareous soils were set to be 1.4 and $1.2 \mathrm{ug} \mathrm{g}^{-1}$, respectively and accordingly, the concentrations of $\mathrm{Mn}$ in the studied soils profiles were lower that the critical levels particularly for soil profiles number 1 and 2 . However, it was close to the critical levels in the rest of soil samples. Comparatively, high levels of $\mathrm{Mn}$ were observed with the deep layer of soil profile number 3 and the top layer of soil profile number 4 . As it has set previously by different studies, the critical levels of $\mathrm{Zn}$ in the alluvial and calcareous soils were 0.9 and $0.7 \mathrm{ug} \mathrm{g}^{-1}$, respectively, samples that collected from soil profiles one and four were lower than or equal to the critical levels. The concentrations of available $\mathrm{Cu}$ in our study were oscillated among high to medium critical level Abo Shelbayea et al. (2016). 


\section{REFERENCES}

Abo Shelbaya, M. A. ; M.M. Abd-elazeim ; W.S. Mohamed and A.M. Menesi (2016).Correlation between soil physiochemical properties and trace metals status of agricultural soils in ElMinia Governorate. Egypt. J. of Agric. Res. \& Develop., 36 (1): $145-160$.

Abou-Shady, A. (2016 a). Effect of separated cathode on the removal of dissolved organic carbon using anode oxidation, Fenton oxidation, and coagulation, J. of Envi.l Chemi. Engi., 4 (1): 704-710.

Abou-Shady, A. (2016 b). Reclaiming salt-affected soils using electroremediation technology: PCPSS evaluation, Electrochimica Acta., 190: 511-520.

Abou-Shady, A. (2017). Recycling of polluted wastewater for agriculture purpose using electrodialysis: Perspective for large scale application, Chem. Engi. J., 323; 1-18.

Azzam, M. A.(2016). Land suitability evaluation for cultivation of some soils in western desert of Egypt, el-Minya governorate using gis and remote sensing. International Journal of Advanced Research, 4(2): 486-503

Elgala, A.M. ; A.S. Ismail and M.A. Ossman (1986). Critical levels of iron, manganese and zinc in Eg., S., J. of Plant Nutrition, 9(37): 267-280.

Esmail, A and S. Sharef (2017). Determination of iron critical level for main agricultural soils cultivated with wheat (Triticum aestivum L.) in Sulaimani, Conference: 5 th scientific conference for Basic Sciences, Univ. of Garmian, Iraq, Kurdistan region Garmian.

Haluschak, P. (2006). Laboratory Methods of Soil Analysis. CanadaManitoba Soil Survey.Pp:1-133

Horvath, B. ; Opara-Nadi and O.F. Beese (2005). A simple method for measuring the carbonate content of soil.Soil Sci. Soc. Am.J., 69: 1066-1068.

Kassim, Y. ; M. Mahmoud ; S. Kurdi and C. Breisinger (2018).An agricultural policy review of Egypt: first steps towards a new strategy, International Food Policy Research Institute, 1-31.

Retsch, G.H. (2009). Sieve analysis taking a close look quality. P.1:52. In. S.B.N.10, 0-8493-7038-8.

Sayed, E. ; P. Riad ; S. Elbeih ; A. Hassan and M. Hagras (2020). Sustainable groundwater management in arid regions 
considering climate change impacts in Moghra region, Egypt, Groundwater for Sustainable Development, 11: 100385.

Soltanpour, P.N. and A.P. Schwab (1977). Anew soil test for simultaneous extraction of macro and micro-nutrients in alkaline soils. Commun Soil Sci.Plant Anal., 8: 195-207.

Soil Testing Laboratory (2021). Recommended chemical soil test procedures for the North Central Region. North Central Regional Research Publication No. 221.

$$
\begin{aligned}
& \text { سلوك بعض العناصر الصغرى وعلاقتها بالوحدات الجيومورفولوجية بأراضى } \\
& \text { أقصى غرب المنيا - مصر } \\
& \text { عبدالسلام محمدعلوه - وليد فؤاد رمضان - أحمد محمد أبوشادى سئ }
\end{aligned}
$$

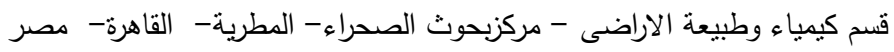

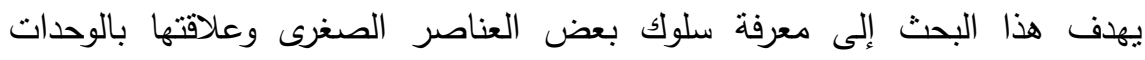

$$
\begin{aligned}
& \text { الجيومورفولوجية بأراضى أقصى غرب المنيا- مصر ولتحقيق ذلك نم جمع الثا وعشرون عينة }
\end{aligned}
$$

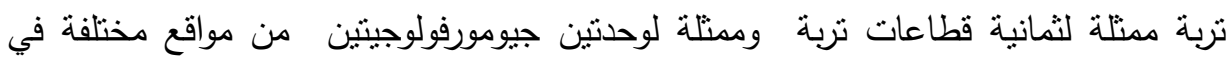

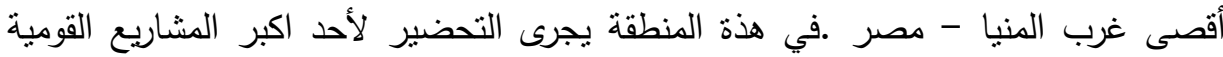

$$
\begin{aligned}
& \text { الضخمة الني تبنتها الحكومات المصرية. و أظهرت النتائج المتحصل عليها أن مستويات }
\end{aligned}
$$

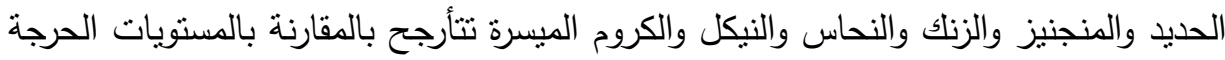

$$
\begin{aligned}
& \text { الدولية .ووجد ان العلاقات بين العناصر الثقيلة المدروسة وخواص التربة الطبيعية والكيميائية }
\end{aligned}
$$

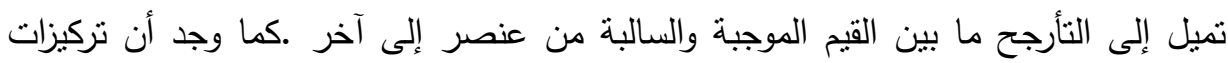

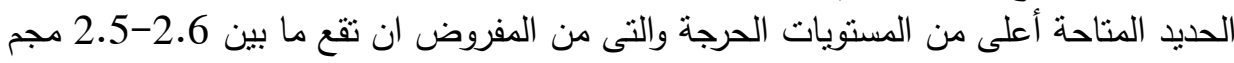

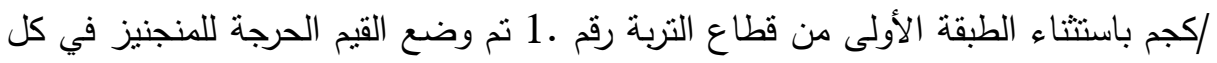

$$
\begin{aligned}
& \text { من التربة الرملية والجيرية لتكون } 1.4 \text { و } 1.2 \text { ميكروجرام /كجم تربة على التهاع التوالي وبالتالي }
\end{aligned}
$$

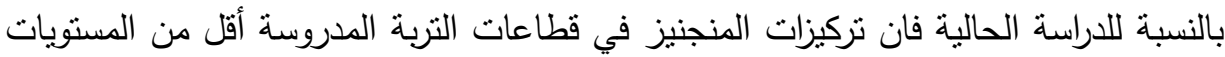

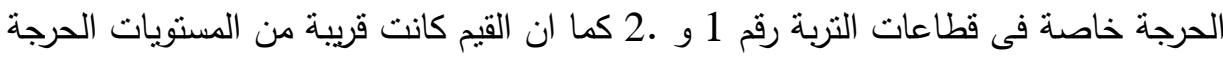

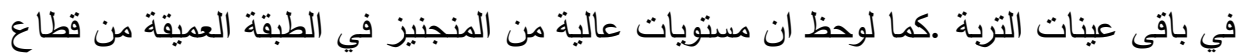

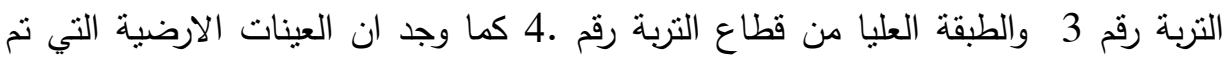

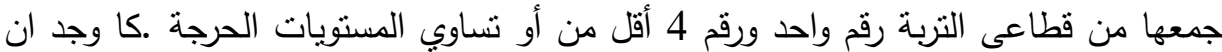

$$
\begin{aligned}
& \text { تركيزات النحاس الميسرة في دراستتا تذبذبت بين المستوفيات الحرجة العاليا والمتوسطة. }
\end{aligned}
$$

